\title{
South-West Benin Coastal Lagoon: Waters and sediments' toxicity and contents in heavy metals during high water period (Togbin to the Mono Mouth)
}

\author{
O. B. M. Lucinde BOCODAHO ${ }^{1,3^{*}}$, Waris Kéwouyèmi CHOUTI ${ }^{1,2}$, R. Arthur $\mathrm{CAKPO}^{2}$ \\ and Daouda MAMA ${ }^{1,2}$
}

${ }^{1}$ Laboratory of Applied Hydrology, National Institute of Water (NIW), University of Abomey-Calavi (UAC), 01 PO: 526 Cotonou, Benin.

${ }^{2}$ Laboratory of Inorganic Chemistry and Environmental, Faculty of Sciences and Technologies (FAST), University of Abomey-Calavi, Benin (UAC), PO: 4521 Cotonou, Benin.

${ }^{3}$ International Chair in Mathematical Physics and Applications (ICMPA-UNESCO CHAIR), University of Abomey-Calavi (UAC), 072 PO: 50 Cotonou, Benin.

*Corresponding author; E-mail: bokomarthe@yahoo.com ; Tel.: +229 96130184

Received: 04-03-2021 $\quad$ Accepted: 25-05-2021 $\quad$ Published: 30-06-2021

\begin{abstract}
The uncontrollable population growth is reaching Benin's rivers, especially the coastal lagoon, raising then the thorny problem of pollution, which is considerably accentuated by the malevolent behavior of the populations. The aim of this paper is to characterize the degree of contamination of the water and sediments of the lagoon in heavy metals $(\mathrm{Cd}, \mathrm{Cr}, \mathrm{Zn}, \mathrm{Cu}, \mathrm{Pb}$ and $\mathrm{Fe})$ through the dosage with the molecular absorption spectrophotometer type DR 3900. At the same time, a cytotoxicity test with Allium cepa will be carried out in order to evaluate the toxic potential of the pollutants responsible for the degradation of the lagoon. The $\mathrm{Cd}, \mathrm{Cu}$ and $\mathrm{Zn}$ contents in the water and sediments far exceed the accepted standards at almost all the stations. The Pollution Index (PI) and geo-accumulation index (Igeo) indicate the existence of polymetallic pollution in the sediments, which is extremely strong and dominated in order to decrease abundance by: $\mathrm{Cd}>\mathrm{Zn}>\mathrm{Cu}>\mathrm{Pb}$. The results of the cytotoxicity test highlight acute toxicity on $82 \%$ of the stations surveyed. The poor states of the coastal lagoon indexed by this study, impose the application of urgent measures of participative management, preservation and sanitation of the coastal zone.
\end{abstract}

(C) 2021 International Formulae Group. All rights reserved.

Keywords: Coastal Lagoon, polymetallic pollution, cytotoxicity, geo-accumulation, Allium cepa.

\section{INTRODUCTION}

Water is an essential resource for all life on earth. Unfortunately, this precious commodity is continually threatened by all forms of pollution, which is becoming increasingly important (Youssao et al., 2011). In fact, in all West African countries, and more particularly in Benin, water bodies have become receptacles for waste of all kinds, especially in these regions where adequate management of household waste and wastewater remains a major challenge (Traoré et al., 2012; Adjagodo et al., 2016). Most of these solid, liquid and valve wastes, which are 
linked in particular to human activities, industrialization and urbanization, are loaded with organic matter and highly toxic nonbiodegradable heavy metals and cause degradation in water bodies while affecting negatively the biotope. However, of all the forms of pollution, metal pollution seems very dangerous and disrupts the natural balance of aquatic ecosystems in the long term (Katemo et al., 2010).

The coastal lagoon of Southwest Benin, notwithstanding the tourist, socio-cultural and economic assets conferred by its rich fauna and flora, is hardly exempt from this sad reality ((NT-ONG, 2006) and (Chouti et al., 2017a). Considering the prominent place occupied by lagoons among the water bodies, several stakeholders from the scientific world have taken an interest in the quality of water and sediments in the lagoons of the sub-region, especially those of Benin. Some authors assessed the heavy metals in the sediments of Porto-Novo lagoon (Benin) and concluded that the sediments of the said lagoon are polluted with chromium, cadmium and mercury (Chouti et al., 2010). Similarly, Chouti et al. (2017a), studied the waters and sediments of the coastal lagoon (South Benin) and showed that this lagoon is polluted by heavy metals, namely copper and zinc.

The little research carried out on the chemical aspect of the coastal lagoon has remained generally synthetic or even limited, especially in relation to polymetallic contamination. In order to deepen these studies through a research with a much broader spectrum, this study focused more on assessing the degree of toxicity of heavy metals $(\mathrm{Fe}, \mathrm{Cr}$, $\mathrm{Cu}, \mathrm{Zn}, \mathrm{Pb}$ and $\mathrm{Cd}$ ) in the waters and sediments of the lagoon in order to characterize better its state of pollution by metals.

\section{MATERIALS AND METHODS \\ Study environment}

The coastal lagoon which is the subject of this study, is one of the most attractive in the sub-region because of its ecotourism aspect. Located in the southwest of Benin, the lagoon environment is part of the 1017 complex and covers the lagoon of Grand-Popo and that of Ouidah (Houéto, 2013). Also known as
Djessin, it extends over an area of $55 \mathrm{~km}^{2}$ from the mouth of the Mono at Akouèta in the West to Togbin in the East of Cotonou. The coastal lagoon is completed by the Gangban channel and is fed by three main rivers, Couffo, Mono and Sazué (Fiogbé et al., 2007). The main anthropogenic activities carried out in the lagoon complex are dominated by agriculture, fishing and animal husbandry. Its maximum depth varies between $0.40 \mathrm{~m}$ to $1.70 \mathrm{~m}$ in low waters and between $1.10 \mathrm{~m}$ to $3.40 \mathrm{~m}$ in high waters (Guillard et al., 1982; PGPE, 2008).

\section{Sampling}

In order to assess heavy metals contamination within the coastal lagoon during high water periods, eleven (11) water and superficial sediment samples were collected from the lagoon bed. The sampling stations were defined approximately in relation to the discharges, the neighboring towns, the presence of latrines and according to the hydrological and environmental contexts of the lagoon environment. After the in situ measurements, water samples were taken a few centimeters from the surface of the water in 1.5 $\mathrm{L}$ plastic bottles and in $25 \mathrm{~L}$ drums for the determination of heavy metals and cytotoxicity test respectively. The sediment samples were collected between 0 and $5 \mathrm{~cm}$ using a linoleum bin and were kept in aluminum foil to protect them from light. Water samples are kept cool in a portable ice chest on the way to the laboratory. Table 1 shows the different sampling stations with their specific criteria.

\section{Physico-chemical parameters}

The physico-chemical parameters that influence the behavior of the heavy metals in the aquatic environment were determined by in situ measurements using the multi-parameter conductivity meter (temperature, depth, redox potential) and the $\mathrm{pH}$ meter $(\mathrm{pH})$ type WTW 3630 IDS. The geo-referencing of the sites is carried out by a GPS of the GARMIN type. At each station, the probe is rinsed with distilled water and then the water is to be sampled before any measurement. The cytotoxicity test was carried out at the Inorganic Chemistry and Environment Laboratory (LACIE) of the Faculty of Science and Technology of the 
University of Abomey-Calavi. As for the determination of heavy metals in water and sediments, it was realized at the Laboratory of the National Public Health Directorate (DNSP/Cotonou). Figure 1 illustrates the distribution of sampling points along the coastal lagoon.

\section{Cytotoxicity test on Allium Cepa}

The toxicity of the lagoon waters was evaluated by the Allium cepa test taking into consideration the root elongation inhibition parameter to determine the efficient concentration $\mathrm{CE}_{50}$. The synthetic environment based on the method of Rank and Nielsen (1997) was used as a control to assess the degree of toxicity. To carry out the test, five different dilution percentages were assigned to the samples through well-defined concentrations in which the root base of onions was introduced. The dilution concentrations for sowing were divided into $0 \%, 25 \%, 50 \%, 75 \%$ and $100 \%$ at the rate of five (5) tests per percentage concentration per sample. The $0 \%$ dilutions correspond to a concentration of $100 \%$ of the synthetic environment and the $100 \%$ represents only the water in the lagoon. The intermediate dilution concentrations of $25 \%, 50 \%$, and $75 \%$ between the $0 \%$ and $100 \%$ concentrations correspond to the proportional mixing of the control with the lagoon water samples. For this test, 275 onion bulbs with a diameter varying between 5 and $8 \mathrm{~cm}$ were used. The 275 onion bulbs, without their outer layer and roots, were placed on 275 glass jars containing the previously diluted solutions, so that the base of the main root was immersed in the solution. Incubation was carried out in the dark for 48 hours while rigorously respecting the concentrations of the predefined dilution percentages at each renewal of the solutions every 24 hours. At the end of the 48 hours of exposure, the length of each of the onion roots put in culture was measured by the glass jar. The root growth observed at each station is compared to that of the synthetic medium percentage by percentage. Samples showing inhibition of root elongation compared to the control mainly in proportions $75 \%$ and $100 \%$ indicate acute toxicity.

\section{Heavy metals dosage}

The HACH LANGE DR 3900 spectrophotometer methodology was adopted.

\section{In the waters}

The waters are subjected to preliminary treatment (mineralization and neutralization of the mineralization product) before being analyzed. Mineralization was based on the $\mathrm{HACH}$ method and the assay was performed using the molecular absorption spectrophotometer (DR 3900) by comparing the reagent-free sample with the reagentcontaining sample. Lead and cadmium were determined using the Dithizone method.

\section{In the sediments}

The sediment samples, previously dried in an oven at $105^{\circ} \mathrm{C}$ and finely ground in a mortar, were dissolved with the DR 3900 molecular absorption spectrophotometer for the determination of $\mathrm{Cd}, \mathrm{Zn}, \mathrm{Pb}, \mathrm{Cr}$, and $\mathrm{Cu}$. Copper was determined by the Bicinchroninate method, lead and cadmium, by the Dithizone method and zinc, by the Zincover method.

\section{Processing of results and evaluation of pollution indices}

Microsoft Excel 2013 software was used to process the data in an objective analysis of correlation between the variables. The realization of the spatial repair map of the sampling points was possible thanks to the ArcGis software.

The diagnosis of metallic contamination in the sediments focused on the determination of the geo-accumulation index (Igeo) and the contamination indices (CI). The geo-accumulation index was initiated by Müller (1981) and makes it possible to evaluate the level of metallic pollution of a sediment in relation to the geological bottom.

$$
\text { Igeo }=\log 2 \frac{\mathrm{Cx}}{1,5 * \text { Fgx }}
$$

Where $\mathbf{C}_{\mathbf{x}}$ stands for the concentration of the heavy metal concerned in the sediment; $\mathbf{F g}_{\mathbf{x}}$ stands for the concentration of the trace metal element concerned in a reference geochemical background; the correction factor of 1.5 considerably minimizes the effect of possible lithological fluctuations in the sediments. A scale of six (6) classes was 
defined on the basis of the values obtained for Igeo. The concentrations of heavy metals in the upper continental crust were taken as reference (Wedepohl, 1995).

The Contamination Index (IC) was used to assess the degree of pollution at each station and throughout the lagoon. It is the ratio between the value considered normal and the one observed in the sediment.

$$
\text { IC }=\frac{\begin{array}{c}
\text { Concentration found in the } \\
\text { sediment }(\mathrm{mg} / \mathrm{kg})
\end{array}}{\begin{array}{c}
\text { Concentration considered as } \\
\text { standard }(\mathrm{mg} / \mathrm{kg})
\end{array}}
$$

IC is translated into three classes according to the Agence du Bassin du Rhône (1990). At the same time, the pollution index (IP) was evaluated by averaging the ratios between the concentrations of heavy metals observed in the sediments and the standards. The PI not only provides information on the polymetallic contamination of the sediments at a given site but also reflects an increase in the toxicity of the heavy metals in the aquatic environment. A pollution Index greater than 1, corresponds to a soil polluted by several metals

\begin{tabular}{|c|c|c|c|}
\hline Designation & Sites & Motifs & $\begin{array}{c}\text { Coordinates } \\
\text { (UTM) }\end{array}$ \\
\hline S1 & Togbin & $\begin{array}{l}\text { Houses, schools, hotel complexes upstream and downstream } \\
\text { of the lagoon }\end{array}$ & $\begin{array}{l}423416 \\
702320\end{array}$ \\
\hline $\mathbf{S 2}$ & Hyo & $\begin{array}{l}\text { Discharge point for household solid waste on both sides of the } \\
\text { lagoon }\end{array}$ & $\begin{array}{l}416937 \\
701593\end{array}$ \\
\hline S3 & Vodounto & $\begin{array}{l}\text { Sacred site reserved for the occult rituals of endogenous } \\
\text { religions. }\end{array}$ & $\begin{array}{l}414844 \\
701689\end{array}$ \\
\hline S4 & Avlékété & $\begin{array}{l}\text { Lagoon-side latrines, solid and liquid waste from concessions } \\
\text { and hospitals }\end{array}$ & $\begin{array}{l}412203 \\
701608\end{array}$ \\
\hline S5 & Aguoin & Villages on the shore and net fishing practice & $\begin{array}{l}408484 \\
700842\end{array}$ \\
\hline S6 & Djègbadji & $\begin{array}{l}\text { Place of artisanal salt extraction and presence of runoff water } \\
\text { collector }\end{array}$ & $\begin{array}{l}399072 \\
699932\end{array}$ \\
\hline S7 & Azizakouè & $\begin{array}{l}\text { Pig farming area, landfill for household solid waste and } \\
\text { domestic sewage; installation of latrines at the edge of the } \\
\text { lagoon }\end{array}$ & $\begin{array}{l}392918 \\
699061\end{array}$ \\
\hline S8 & Dondji & $\begin{array}{l}\text { Very accentuated coastal erosion and opening of the lagoon } \\
\text { on the Aho Channel with the inflow of water from Ahémé } \\
\text { Lake. }\end{array}$ & $\begin{array}{l}386919 \\
697647\end{array}$ \\
\hline S9 & $\begin{array}{l}\text { Bouche du } \\
\quad \text { Roi }\end{array}$ & $\begin{array}{l}\text { Point of exchange between the Atlantic Ocean and the fluvio- } \\
\text { lagunar complexes: crossroads of the hydrological phenomena } \\
\text { which govern the whole aquatic ecosystem of the Couffo-lake } \\
\text { Ahémé-channel Aho-coastal lagoon. }\end{array}$ & $\begin{array}{l}381641 \\
696342\end{array}$ \\
\hline S10 & Avlo & Two villages face to face on the bank separated by the lagoon & $\begin{array}{l}377930 \\
695844\end{array}$ \\
\hline S11 & $\begin{array}{l}\text { Mono } \\
\text { Entry }\end{array}$ & Mouth of the lagoon and the Mono river & $\begin{array}{l}372808 \\
694914\end{array}$ \\
\hline
\end{tabular}
(Chon et al., 1998).

Table 1: Water and sediments sampling sites per selection motif. 


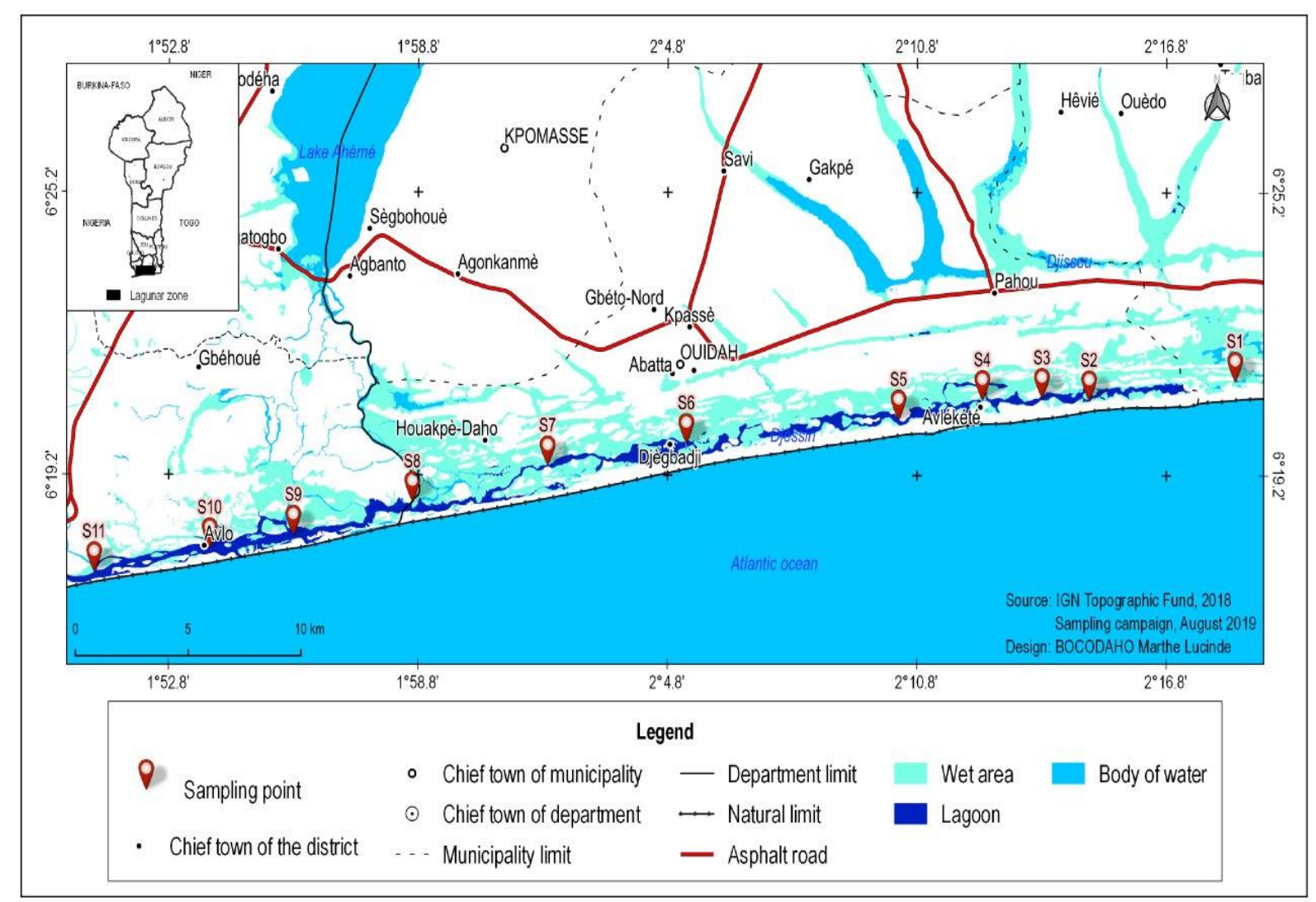

Figure 1: Distribution of sampling points along the Coastal Lagoon.

\section{RESULTS}

\section{Physico-chemical parameters of water}

Figure 2 illustrates the measurements of the physico-chemical parameters influencing the distribution of heavy metals. Water temperature is involved in almost all physical, chemical and biological reactions. In the waters of the lagoon, a variation of 27.3 to $29.5{ }^{\circ} \mathrm{C}$ was observed for the temperature depending on the stations. The highest temperature was observed at station $\mathrm{S} 1$, and the lowest at station $\mathrm{S} 9$ with an average of about $28^{\circ} \mathrm{C}$. As for $\mathrm{pH}$, it is a factor that increases the solubility of heavy metals. The $\mathrm{pH}$ values, ranging from 7.85 (S10) to 7.55 (S9) indicate that the lagoon waters are slightly basic. The Oxidation-Reduction Potential shows negative values over all sampled points and varies between -62.1 and -44.9 with very little significant variation. The highest value was obtained at station S10 and the lowest at station
S9. The depth in the coastal lagoon during high water increases from 0.8 to $2.65 \mathrm{~m}$. The lagoon appears to be deeper at station S10 and shallow at station $\mathrm{S} 1$.

\section{Waters metallic contamination.}

In most samples, the results of the heavy metals contents assays show the presence of $\mathrm{Fe}, \mathrm{Cu}, \mathrm{Cd}, \mathrm{Pb}, \mathrm{Cr}$ and $\mathrm{Zn}$ exceeding the WHO (2011) guidelines for water quality and Canadian standards. Recorded $\mathrm{Cu}, \mathrm{Pb}$ and $\mathrm{Cd}$ values are all above standards in all the eleven water samples analyzed (Figures: 3c; 3e; 3f). For $\mathrm{Zn}$ and $\mathrm{Fe}$, grades are above standards on 9 stations with the exception for stations $\mathrm{S} 2$ and $\mathrm{S} 4$ (Figures $3 \mathrm{a}$ and $3 \mathrm{~b}$ ). Chromium levels fluctuate between $0.01 \mathrm{mg} / \mathrm{L}$ at station $\mathrm{S} 6$ and $0.46 \mathrm{mg} / \mathrm{L}$ at station $\mathrm{S} 4$. With the exception for station $\mathrm{S6}$, which shows a level $(0.01 \mathrm{mg} / \mathrm{L})$ below the standards $(0.05 \mathrm{~m} / \mathrm{L})$, all the 
remaining stations (91\%) show very high chromium levels (Figure 3d).

A comparison of heavy metals concentrations in water with the surface water quality criteria for the protection of aquatic life (MDDELCC, 2015) shows that at all stations, the concentrations of $\mathrm{Zn}, \mathrm{Cu}, \mathrm{Pb}$ and $\mathrm{Cd}$ significantly exceed the criteria for both chronic (CVAC) and acute effects (CVAA). Chromium only approaches the limit at station S6 for CVAC and CVAA. On the other hand, all of the remaining ten (10) stations show values above CVAC and CVAA. Iron shows elevated levels relative to CVAC at all stations including stations S10 and S11. However, on stations S1, S2, S3, S4, S5, S6 and S7, Fe grades remained below the CVAA except on stations S9, S10, S11 where grades are above the CAAC. At station $\mathrm{S} 8$, the $\mathrm{Fe}$ grade is slightly at the limit of the CVAA.

\section{Metallic contamination of sediments}

Figure 4 shows the spatial variation of the concentrations of heavy metals $(\mathrm{Zn}, \mathrm{Cu}$, $\mathrm{Cd}, \mathrm{Pb}$ and $\mathrm{Cr}$ ) in the sediments in relation to the thresholds over all the sampling stations. In sediments, analyses report concentrations far above the World Health Organization (WHO) sediment quality guidelines at almost all stations for $\mathrm{Zn}, \mathrm{Cu}, \mathrm{Cd}$ and $\mathrm{Pb}$. The exception is about $\mathrm{Cr}$ with concentrations far below the threshold value for minor effects. The concentrations obtained for $\mathrm{Cu}$ at all stations give a maximum value of $149.987 \mathrm{mg} \cdot \mathrm{kg}^{-1}$ with a mean value of $94.28 \mathrm{mg} \cdot \mathrm{kg}^{-1}$. For $\mathrm{Zn}$, the maximum concentration was as high as 1825 $\mathrm{mg} \cdot \mathrm{kg}^{-1}$ at station $\mathrm{S} 1$, and $846 \mathrm{mg} \cdot \mathrm{kg}^{-1}$ at station S5. Cr had a maximum concentration of 20 $\mathrm{mg} . \mathrm{kg}^{-1}$ at station $\mathrm{S} 1$ and a minimum of 8.8 mg. $\mathrm{kg}^{-1}$ at station $\mathrm{S} 11$. As for $\mathrm{Cd}$, the maximum value of $8.6 \mathrm{mg} \cdot \mathrm{kg}^{-1}$ is obtained at station $\mathrm{S} 9$. And as for $\mathrm{Pb}$, it comes out with a maximum of $63.2 \mathrm{mg} \cdot \mathrm{kg}^{-1}$ at station S7 and a minimum of $32.4 \mathrm{mg} \cdot \mathrm{kg}^{-1}$ at station S5.

Table 5 presents the different indices of geoaccumulation and contamination of the lagoon sediments according to the eleven (11) stations. Following the Igeo indices results, $\mathrm{Cd}$ and $\mathrm{Zn}$ have the same trends over the majority of stations, with values above 4 and 5 for $\mathrm{Cd}$ and values between 3 and 5 for $\mathrm{Zn}$. The sediments of the coastal lagoon then tend towards strong or even extreme pollution for $\mathrm{Zn}$ and $\mathrm{Cd}$. Concerning $\mathrm{Cu}$ and $\mathrm{Pb}$, the Igeo indices waver between 0.35 and 2.80 for all stations; the sediments are therefore moderately contaminated by $\mathrm{Pb}$ and $\mathrm{Cu}$ at all stations. Unlike other heavy metals, Cr exhibits negative Igeo index values at all stations, indicating an absence of chromium contamination of sediments.

Regarding the contamination indices (IC), the values [3.28 to 9.57] obtained underline a significant pollution of all the stations by $\mathrm{Cd}$ as opposed to $\mathrm{Cr}$, whose IC indices are negligible and far below 3 at all stations. $\mathrm{Pb}$ directly follows $\mathrm{Cr}$ with relatively low IC indices at all stations. The sediments of the coastal lagoon are not polluted by $\mathrm{Cr}$ but slightly affected by $\mathrm{Pb}$. The IC indices in $\mathrm{Zn}$ are above 10 for stations $\mathrm{S} 1$ and S6, and between [3 and 9] for the other 9 stations. Stations S1 and S6 have sediments heavily polluted by $\mathrm{Zn}$ while sediments at stations $\mathrm{S} 2$, S3, S4, S5, S7, S8, S9, S10 and S11 are moderately polluted by $\mathrm{Zn}$. In total, $82 \%$ of the samples are in the Zn-polluted class and 18\% are already in the risk zone. $\mathrm{Cu}$ is characterized by a contamination index below 3 but not negligible at stations $\mathrm{S} 3, \mathrm{~S} 4, \mathrm{~S} 8$ and $\mathrm{S} 11$ as it is relatively close to the limit. However, at stations S1, S2, S5, S6, S7, S9 and S10 the IC indices are above 3 with $64 \%$ of sites contaminated by $\mathrm{Cu}$.

$\mathrm{Cr}$ and $\mathrm{Pb}$, as opposed to $\mathrm{Zn}, \mathrm{Cu}$ and $\mathrm{Cd}$ revealed contamination indices below 3 on all stations. This classifies the lagoon to the normal class for lead and chromium. Ultimately, it follows that the coastal lagoon is highly polluted with $\mathrm{Cu}, \mathrm{Cd}$, and $\mathrm{Zn}$ at all stations in general and more specifically at station S1 and S6. The lagoon is classified as a normal area for chromium and lead.

The sum of the contamination indices was used to determine the pollution index (PI):

$$
\begin{array}{r}
\mathrm{IP}=\left[\frac{\text { Zinc }}{150}+\frac{\text { Copper }}{28}+\frac{\text { Chromium }}{55}\right. \\
\left.+\frac{\text { Cadmium }}{0,9}+\frac{\text { Lead }}{42}\right]
\end{array}
$$


IP $=3.70$ far above 1 . The lagoon is then subject to a polymetallic pollution.

Figure 5 shows, on the one hand, the inhibition of root lengths as a function of dilution concentrations and, on the other hand, the dose- lethal response. High positive and moderate correlations were observed between $\mathrm{Zn}, \mathrm{Fe}, \mathrm{Cd}$ and root length inhibition of onions indexing their likely common sources from anthropogenic activities.

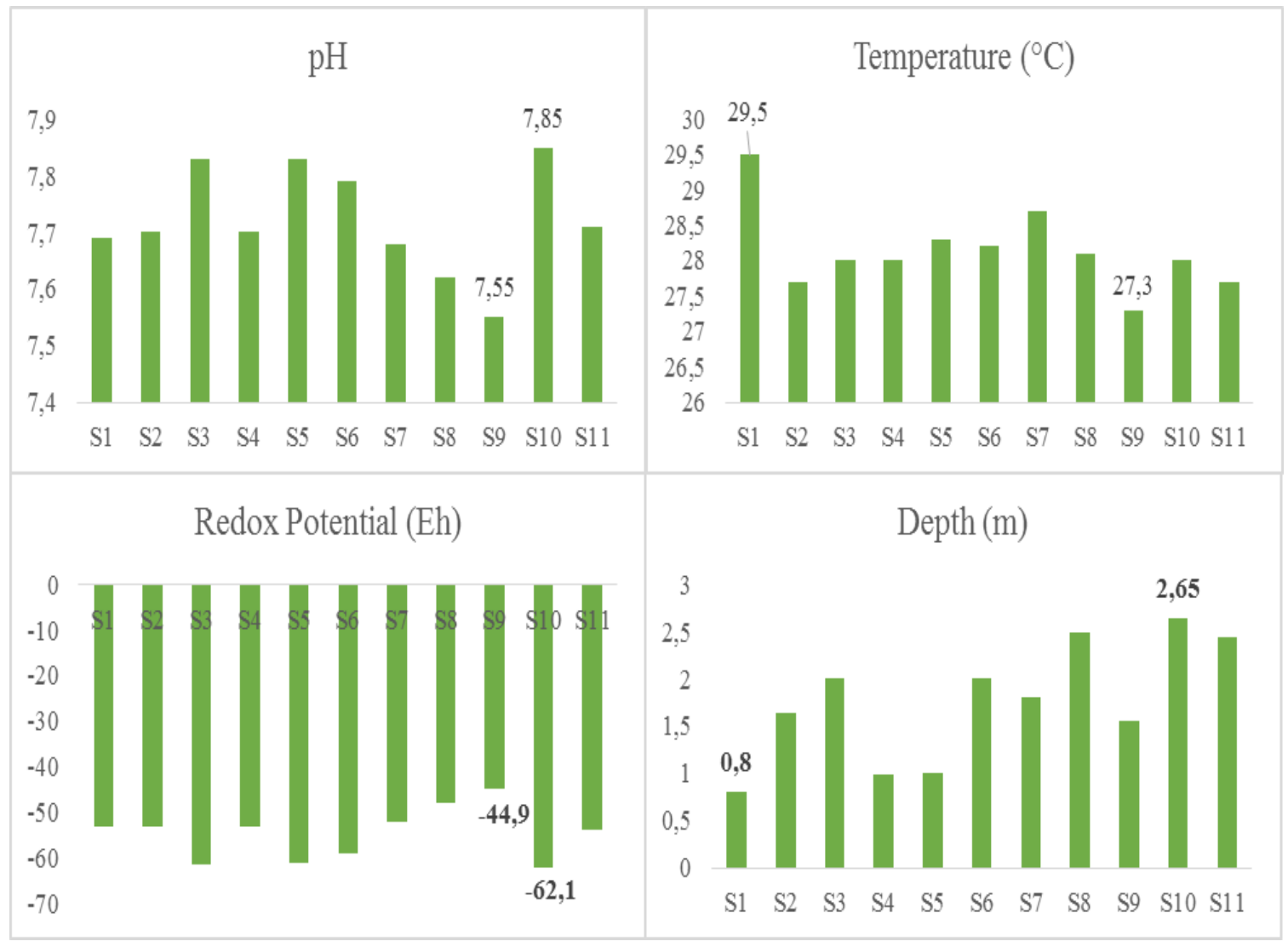

Figure 2: Spatial variation of the physico-chemical parameters ( $\mathrm{pH}$, redox potential, temperature and depth) of the Coastal Lagoon waters.

Table 2: Evaluation of metallic contamination of sediments from the Igeo (Müller, 1981).

\begin{tabular}{lll}
\hline Class & Value & Sediment degree of pollution \\
\hline $\mathbf{1}$ & $\mathbf{0} \leq$ Igeo $<\mathbf{1}$ & No pollution to medium pollution \\
\hline $\mathbf{2}$ & $\mathbf{1} \leq$ Igeo $<\mathbf{2}$ & Medium pollution \\
\hline $\mathbf{3}$ & $\mathbf{2} \leq$ Igeo $<\mathbf{3}$ & Medium pollution to high level pollution \\
\hline $\mathbf{4}$ & $\mathbf{3} \leq$ Igeo $<\mathbf{4}$ & High level pollution \\
\hline $\mathbf{5}$ & $\mathbf{4} \leq$ Igeo $<\mathbf{5}$ & High level pollution to extreme pollution \\
\hline $\mathbf{6}$ & $\mathbf{5} \leq$ Igeo & Extreme pollution \\
\hline
\end{tabular}


O. B. M. L. BOCODAHO et al. / Int. J. Biol. Chem. Sci. 15(3): 1249-1263, 2021

Table 3: Classification of water quality according to pollution indices.

\begin{tabular}{lll}
\hline Class & Value & Pollution state \\
\hline 1 & $\mathbf{C I}<\mathbf{3}$ & Normal area \\
\hline 2 & $\mathbf{3} \leq \mathbf{C I}<\mathbf{1 0}$ & Polluted area \\
\hline 3 & $\mathbf{1 0} \leq \mathbf{C I}$ & High risk area \\
\hline
\end{tabular}

Table 4: Sediments geo-accumulation and contamination indices.

\begin{tabular}{|c|c|c|c|c|c|c|c|c|c|c|c|c|c|}
\hline 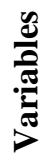 & 递 & $\bar{\infty}$ & బู & $\ddot{n}$ & फे & $n$ & ஜ & ns & $\infty$ & हे & $\stackrel{\theta}{\text { s }}$ & $\overrightarrow{\bar{B}}$ & 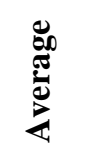 \\
\hline \multirow{2}{*}{$\Xi$} & Igeo & 2,32 & 2,33 & 1,89 & 1,60 & 2,13 & 2,50 & 2,33 & 0,78 & 2,80 & 1,89 & 2,13 & 2,06 \\
\hline & Ic & 3,84 & 3,85 & 2,80 & 2,33 & 3,35 & 4,34 & 4,34 & 1,31 & 5,35 & 2,84 & 3,35 & $\mathbf{3 , 4 3}$ \\
\hline \multirow{2}{*}{$\widehat{\mathbf{N}}$} & Igeo & 4,55 & 3,57 & 3,73 & 3,49 & 2,91 & 3,97 & 3,19 & 2,93 & 3,02 & 3,51 & 3,18 & 3,46 \\
\hline & Ic & 12,17 & 8,93 & 9,95 & 8,41 & 5,64 & 11,75 & 6,84 & 5,70 & 6,09 & 8,55 & 6,79 & 8,26 \\
\hline \multirow{2}{*}{$\dot{U}$} & Igeo & $-1,44$ & $-1,78$ & $-1,75$ & $-1,70$ & $-1,39$ & $-1,93$ & $-1,95$ & $-2,21$ & $-1,76$ & $-1,66$ & $-2,58$ & $-1,83$ \\
\hline & Ic & 0,35 & 0,28 & 0,28 & 0,29 & 0,36 & 0,25 & 0,25 & 0,21 & 0,28 & 0,30 & 0,16 & $\mathbf{0 , 2 7}$ \\
\hline \multirow{2}{*}{$\bar{U}$} & Igeo & 4,88 & 4,63 & 4,51 & 5,45 & 5,79 & 4,58 & 4,72 & 4,56 & 5,84 & 4,30 & 4,89 & 4,92 \\
\hline & Ic & 4,90 & 4,14 & 3,80 & 7,29 & 9,19 & 3,98 & 4,39 & 3,93 & 9,57 & 3,28 & 4,94 & 5,40 \\
\hline \multirow{2}{*}{$\vec{a}$} & Igeo & 0,93 & 1,41 & 0,98 & 0,56 & 0,35 & 0,65 & 1,31 & 0,87 & 0,78 & 0,70 & 0,91 & $\mathbf{0 , 8 6}$ \\
\hline & Ic & 1,16 & 1,61 & 1,19 & 0,90 & 0,77 & 0,95 & 1,50 & 1,11 & 1,04 & 0,99 & 1,14 & 1,12 \\
\hline
\end{tabular}

Table 5: Correlation matrix between metals and inhibition of root lengths.

\begin{tabular}{lrrrrrrrrrrr}
\hline & \multicolumn{1}{l}{ Fe } & \multicolumn{1}{c}{ Cu } & \multicolumn{1}{l}{ Zn } & Cr & Pb & Cd & E0 & E25 & E50 & E75 & E100 \\
\hline Fe & 1 & & & & & & & & & & \\
Cu & $\mathbf{0 , 6 0}$ & 1 & & & & & & & & & \\
Zn & $\mathbf{0 , 4 5}$ & 0,13 & 1 & & & & & & & & \\
Cr & 0,11 & 0,13 & $-0,18$ & 1 & & & & & & & \\
Pb & 0,14 & 0,33 & $\mathbf{0 , 5 4}$ & $-0,31$ & 1 & & & & & & \\
Cd & $\mathbf{0 , 7 9}$ & 0,18 & $\mathbf{0 , 6 5}$ & 0,15 & 0,07 & 1 & & & & & \\
E0 & 0,30 & 0,007 & $\mathbf{0 , 6 6}$ & $-0,08$ & 0,38 & 0,27 & 1 & & & & \\
E25 & $\mathbf{0 , 4 8}$ & 0,11 & $\mathbf{0 , 7 5}$ & $-0,09$ & $\mathbf{0 , 3 8}$ & $\mathbf{0 , 4 3}$ & $\mathbf{0 , 9 7}$ & 1 & & & \\
E50 & $\mathbf{0 , 5 1}$ & 0,37 & $\mathbf{0 , 8 0}$ & 0,03 & $\mathbf{0 , 4 8}$ & $\mathbf{0 , 4 7}$ & $\mathbf{0 , 8 2}$ & $\mathbf{0 , 8 7}$ & 1 & & \\
E75 & 0,12 & 0,20 & $\mathbf{0 , 5 9}$ & 0,15 & $\mathbf{0 , 3 8}$ & 0,15 & $\mathbf{0 , 5 5}$ & $\mathbf{0 , 5 9}$ & $\mathbf{0 , 7 7}$ & 1 & \\
E100 & $-0,11$ & 0,22 & 0,29 & 0,21 & 0,34 & $-0,07$ & 0,20 & 0,23 & $\mathbf{0 , 4 5}$ & $\mathbf{0 , 8 4}$ & \\
\hline
\end{tabular}




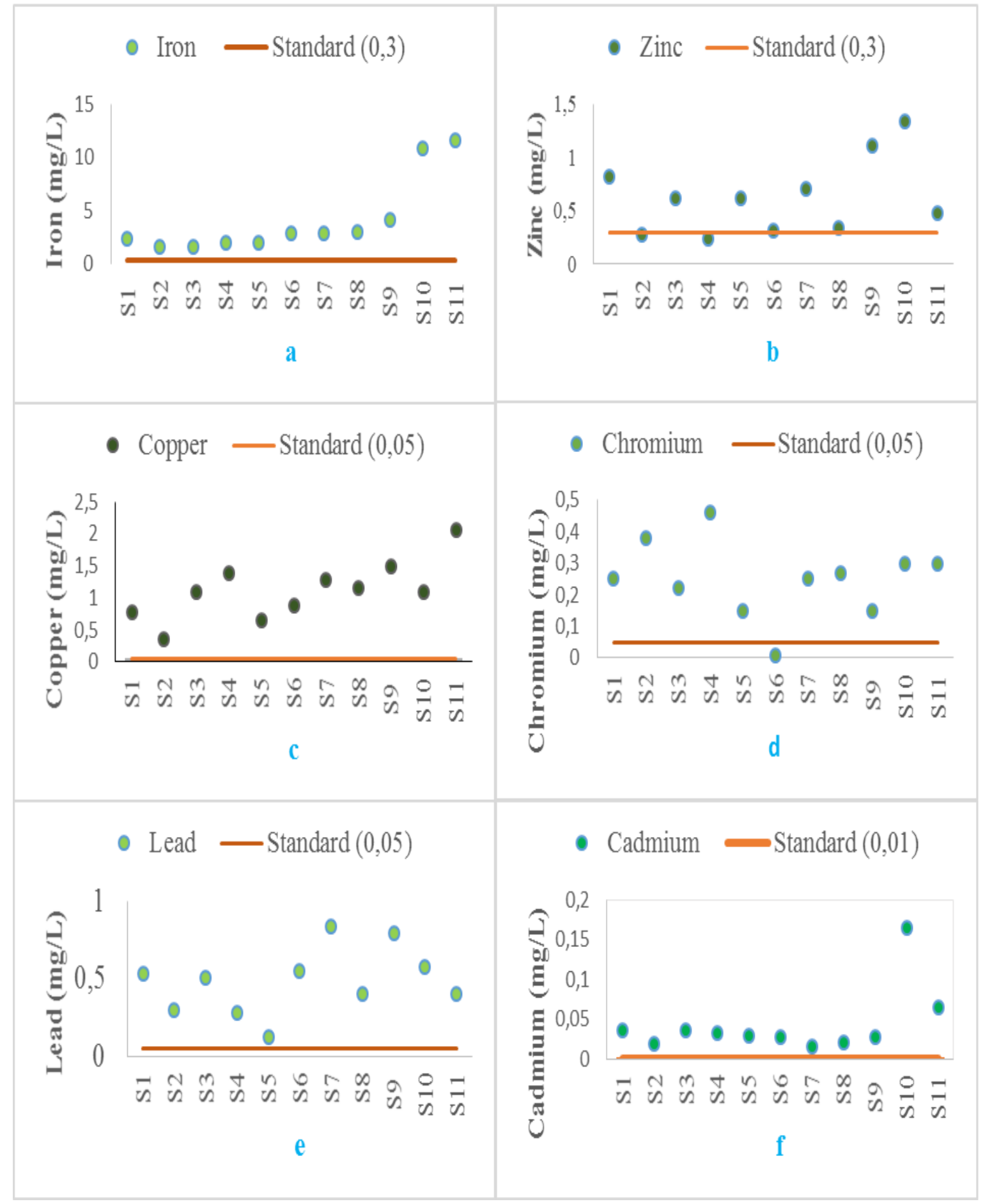

Figure 3: Spatial variation in heavy metals $(\mathrm{Fe}, \mathrm{Zn}, \mathrm{Cu}, \mathrm{Cr}, \mathrm{Pb}$ and $\mathrm{Cd}$ ) levels in the Coastal Lagoon waters. 


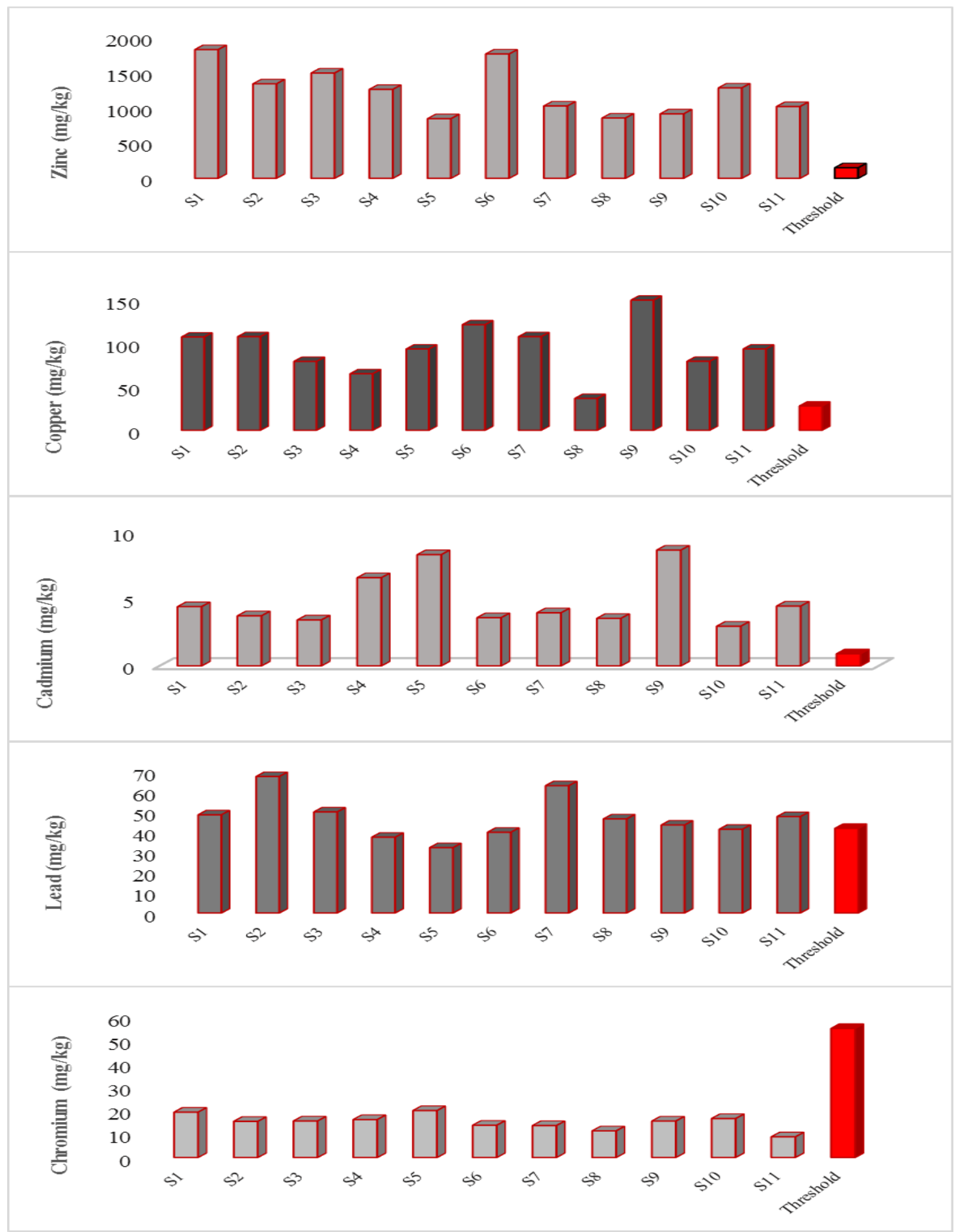

Figure 4: Spatial variation of heavy metals $(\mathrm{Cu}, \mathrm{Zn}, \mathrm{Cd}, \mathrm{Pb}$ and $\mathrm{Cr})$ in the sediments of Coastal Lagoon. 

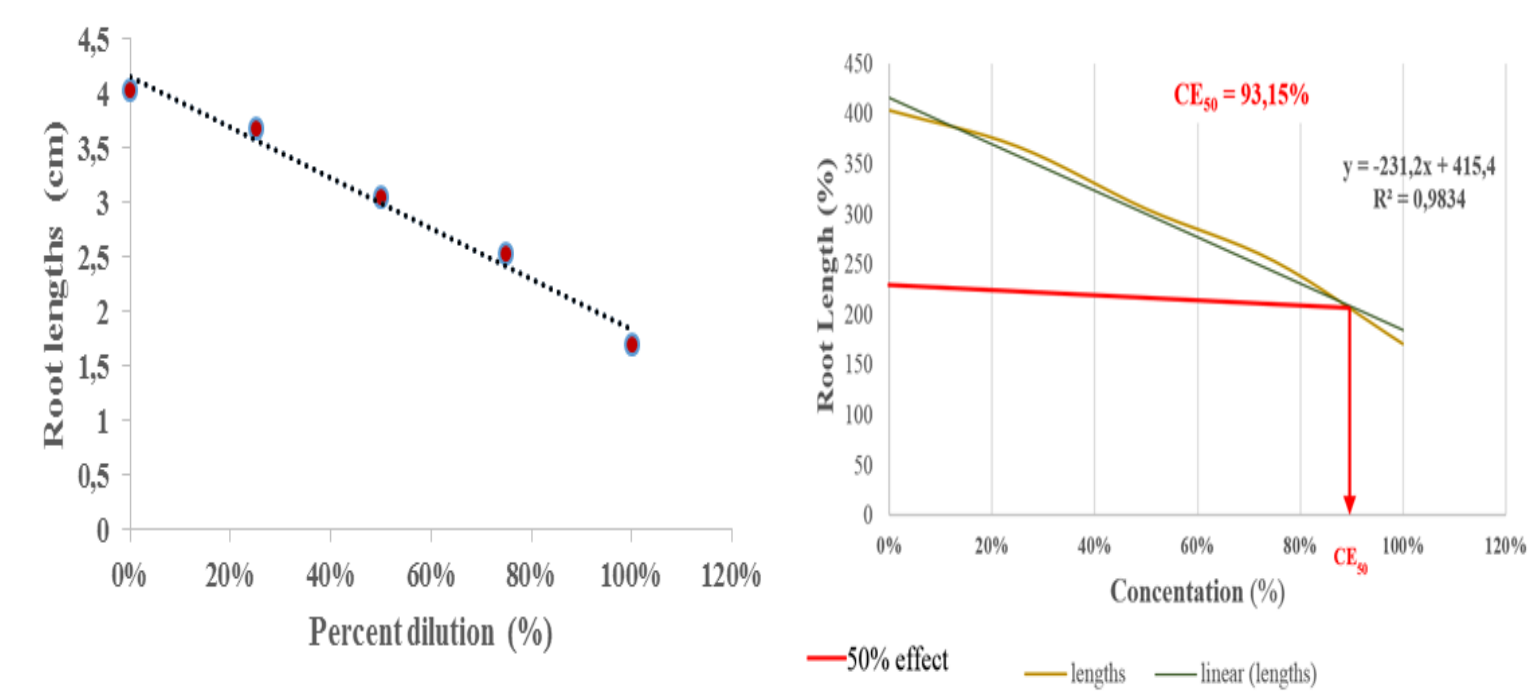

Figure 5: Inhibitory effect of lagoon water on root elongations and dose-response curve for the evaluation of the toxicity test.

\section{DISCUSSION}

The coastal lagoon of Southwest Benin is located in an area of intense human activities such as fishing in all its forms, salt farming, pig breeding, agriculture etc. These anthropic pressures interact on the ecological quality of the ecosystem. Faced with this situation, the present study was interested in the aspect of the water and sediment compartments of the said lagoon. In addition to the cytotoxicity test, the determination of heavy metals in water and sediments allowed to assess the degree of pollution of the coastal lagoon.

The measurements of the hydogen and oxidation-reduction potentials showed that the lagoon environment is reductive and characterized by slightly basic waters. The basic $\mathrm{pH}$ observed at all the stations favors the accumulation of heavy metals in the sediments unlike the acidic pH. Indeed, Brin (2007) stressed that at the water-sediment interface, the processes of accumulation of heavy metals are very sensitive to alkaline environment. The results of the root length inhibition test are more revealing the toxicity of the stations. Approximately $91 \%$ of the stations (10 out of 11) showed a decrease in root elongation compared to the analytical control. In contrast, station S3 shows almost identical root growth to the analytical control. The onion root length inhibition response is thought to be caused by the presence of toxic contaminants in the water. In fact, the ten (10) stations that cover the majority of the population all present high toxicities unlike the only station S3, a place of worship protected by endogenous religions. The surrounding population upstream and downstream of these ten stations generates daily massive waste directly dumped into the lagoon and its surroundings. The growth of onion roots at station S3 indicates a lack of toxicity at this station due to the fact that this station (S3) is protected by traditional rituals and has a reduced population compared to the other stations. There is a proportionality between the concentration of heavy metals in the water and the degree of inhibition of root elongation with a correlation coefficient $r^{2}=$ 
0.98. Similar observations were made by Chouti et al. (2017a) in the same lagoon and Cakpo (2015) in the Porto-Novo lagoon. Given that the Allium cepa test has been used by many researchers mainly as a bio-indicator of environmental pollution (Leme, 2008; Bagatini et al., 2009), it is easy to conclude that the waters of the coastal lagoon are teeming with toxic pollutants that participate in the inhibition of onion root length.

The dosage of heavy metals has shown results significantly higher than the minor effects thresholds (MET) values at most stations in both water and sediment for $\mathrm{Cd}, \mathrm{Zn}$, and $\mathrm{Cu}$. For these heavy metals, the highest concentrations were observed at the stations near the discharges, those downstream of the discharges and those below decks. This can be explained by the existence of toxic metallic pollutants in these discharges from anthropogenic activities that infiltrate directly or by leaching and accumulate in the sediments. Comparison of heavy metals levels in water with water quality criteria for the protection of aquatic life reveals excess of criteria for $\mathrm{Cd}, \mathrm{Zn}$ and $\mathrm{Cu}$ for both chronic and acute effects.

In general, sediments constitute a nest of storage and metal contamination depending on the conditions of the aquatic environment. The assessment of the quality of the sediments of the coastal lagoon through the indices of contamination and geo-accumulation for $\mathrm{Cd}$, $\mathrm{Zn}$, and $\mathrm{Cu}$ highlights two classes of pollution: the first class is constituted by the sediment stations with sediments highly or even extremely charged in $\mathrm{Cd}$ and $\mathrm{Zn}$. The second category consists of stations characterized by sediments moderately polluted by $\mathrm{Cu}$. As for $\mathrm{Pb}$ and $\mathrm{Cr}$, two classes are also observed: the third category presents stations with low $\mathrm{Pb}$ contents in the sediments and the last class is made up of stations not contaminated by $\mathrm{Cr}$ in the sediments. Coulibaly et al. (2016) obtained almost similar results in the sediments of the bay of Bietry (Ivory Coast) assessed at $2 / 3$ of moderate or even extreme pollution according to the classification of the Igeo pollution index.

$\mathrm{Zn}$ is strongly present at all stations in both water and sediments. $\mathrm{Cu}$ comes mainly from agricultural activities (notably due to the use of copper sulphate), wastewater discharges and soil erosion. Contamination of the lagoon with $\mathrm{Cd}$ and $\mathrm{Cu}$ is believed to be related to anthropogenic activities. These results confirm those of Chouti et al. (2017a) for the same lagoon in which they discovered very high $\mathrm{Cu}$ and $\mathrm{Zn}$ grades in the water and sediments. The $\mathrm{Cu}$ and $\mathrm{Zn}$ pollution of the lagoon is becoming increasingly significant as the current grades are twice those of 2017.

These results are also similar to those of Dèdjiho (2014) and Chouti et al. (2017b) at the Ahémé lake level, which all found very high levels of $\mathrm{Cu}$ and $\mathrm{Zn}$ in the water and sediments of this lake. The sources of zinc pollution of the coastal lagoon could be explained by the inflow of water from Ahémé lake via the Aho channel. Also, the waste discharges observed at $90 \%$ of the stations could be sources of $\mathrm{Cu}$ and $\mathrm{Zn}$ contamination of the lagoon. $\mathrm{Cu}$ and $\mathrm{Zn}$ show the same trend with a remarkable increase in the downstream part of the lagoon (S1, S6). Indeed, the high pollution of $\mathrm{Zn}, \mathrm{Cu}$, and $\mathrm{Cd}$ within the lagoon is thought to be due to inputs from Ahémé lake separating the lagoon by 15 $\mathrm{km}$, and to discharges of domestic effluents from downstream villages. According to Yehouénou (2005), the stations downstream of the discharges are much more impacted by pollution than those upstream.

The abundance of these heavy metals in the sediments is linked with the composition of the mother rock (alumino-silicates) but largely to discharges from anthropogenic activities. $\mathrm{Cr}$ is negligible in sediments at all stations. The lagoon is therefore not polluted by chromium. The high levels of $\mathrm{Cr}$ observed in the water versus the low levels in the sediment could be explained by the fact that during high water, 
there was a transfer of $\mathrm{Cr}$ loading from the sediment compartment to the water compartment of the lagoon. The $\mathrm{Cd}$ contents are not negligible on all sites. As for $\mathrm{Pb}$, concentrations ranged from $67.7 \mathrm{mg} \cdot \mathrm{kg}^{-1}$ at station S2 to 32.4 mg. $\mathrm{kg}^{-1}$ at station $\mathrm{S} 5$. Pb and $\mathrm{Cr}$ would be of terrigenous origin while $\mathrm{Cu}, \mathrm{Zn}$ and $\mathrm{Cd}$ would come from anthropogenic sources. The accentuated presence of heavy metals ( $\mathrm{Zn}, \mathrm{Cu}, \mathrm{Cd}$ ) at the level of S1, S2, S4, $\mathrm{S} 5, \mathrm{~S} 6, \mathrm{~S} 9$, may be related to their proximity to discharges, schools, markets and technical plants. However, the sources are not identified for station $\mathrm{S} 3$.

The Pollution Index (PI), far exceeding 1 , reflects a lagoon polluted by several heavy metals. These results are in line with those of Chouti et al. (2010), who concluded that the Porto-Novo lagoon was polluted by several heavy metals.

In this study, the ten (10) sites most exposed to discharges and agglomerations proved to be the most polluted, unlike the only site isolated from discharges and protected by endogenous cults. The waters and sediments of the coastal lagoon of Southwest Benin are thus $90 \%$ influenced by anthropic activities and $10 \%$ by natural phenomena. The trends indicate a metal pollution strongly anthropized within the lagoon.

\section{Conclusion}

Anthropogenic activities generate solid household waste and wastewater which, discharges of into aquatic environments, without any prior treatment, can have serious and irreversible consequences on the aquatic ecosystem, which is the receiving environment. The objective of this study was to characterize the state of the coastal lagoon and its degree of iron, copper, zinc, chromium, cadmium and lead toxicity during high water periods in order to estimate the eco-toxicological risks to which fish species and population are exposed. The results showed that the waters and sediments of the coastal lagoon are characterized by the presence of $\mathrm{Cu}, \mathrm{Zn}, \mathrm{Cr}, \mathrm{Cd}$ and $\mathrm{Pb}$ at all the stations but more particularly $\mathrm{Cu}, \mathrm{Cd}$ and $\mathrm{Zn}$. Levels of these heavy metals in both water and sediments are non-standard at most stations. This constitutes a high risk for the aquatic environment. This study highlights a problem of toxic exposure related to the contamination of the lagoon with heavy metals, especially in Togbin, Djègbadji and Avlo. Waste management must be reviewed at the level of this water body.

\section{COMPETING INTERESTS}

The authors declare that they have no competing interests.

\section{AUTHORS' CONTRIBUTIONS}

OBMLB has initiated and developed the research. WKC and DM coordinated and contributed to the writing process. RAC participated in the analysis protocol. All authors read and approved the final manuscript.

\section{ACKNOWLEDGEMNTS}

The authors would like to thank $\mathrm{Mr}$ Elias POGNON for his expertise during the analyses.

\section{REFERENCES}

Adjagodo A, Agassounon DTM, Kelome NC, Lawani R. 2016. Flow of pollutants linked to anthropic activities, risks on worldwide surface water and food chain resource: literature review. Int. J. Biol. Chem. Sci., 10(3): 1459-1472. DOI: http://dx.doi.org/10.4314/ijbcs.v10i3.43

Agence du Bassin de Rhône. 1990. La pollution du Rhône. Agence du Bassin de Rhône, Greenpeace, projet mer méditerranée (Août 1990).

Brin ME. 2007. Etude de la biodisponibilité des contaminants (éléments traces métalliques et phosphore) dans les sédiments du lac Saint-Augustin 
(Québec). Mémoire de Maîtrise en Génie Civil, Faculté des Sciences et Génie de l’Université Laval, Québec, 199 p.

Cakpo A, Sagbo E, Mama D, Soumanou M. 2015. Évaluation de la cytogénotoxicité des sites de pollution du Pont et d'Accron de la lagune de Porto-Novo. Journal of Applied Biosciences, 87: 8076-8084. DOI: http://dx.doi.org/10.43314/jab.v87i1.8

Chon HT, Ahn JS, Jung MC. 1998. Seasonal Variations and Chemical Forms of Heavy Metals in Soils and dusts from the Satellite Cities of Seoul, Korea. Environ. Geochem. Hlth., 20(2): 77-86. DOI: 10.1023/A: 1006593708464.

Chouti WK, Chitou NE, Kelome N, Kpako BBH, Vlavonou DH, Tossou M. 2017a. Caractérisation physico-chimique et étude de la toxicité de la lagune côtière, De Togbin à Grand-Popo (Sud-Ouest Bénin). European Scientific Journal, 13(27): 131-151. DOI: dx.doi.org/10.19044/esj.

Chouti WK, Bocodaho L, Adandédji FM, Kpako BB, Dèdjiho A, Tometin L, Mama D. 2017b. Zinc toxicity and sequential extraction in water and sediments of tropical lake: A case study of Ahémé Lake in Benin. Res. J. Chem. Sci., 7(5): 23-30.

Chouti W, Mama D, Changotade O, Alapini F, Boukari M. 2010. Étude des éléments traces métalliques contenus dans les sédiments de la lagune de Porto-Novo (Sud Bénin). Journal of Applied Biosciences, 34: 2186-2197.

Coulibaly AS, Monde S, N'Guessan AY, Aka K. 2011. Spéciation chimique des éléments traces métalliques dans un environnement lagunaire confiné : la baie de Bietry. Int. J. Biol. Chem. Sci., 5(6): 2543-2556.

DOI: http://dx.doi.org/10.4314/ijbcs.v5i6.33
Dèdjiho CA. 2014. Etude diagnostique de la pollution chimique des plans d'eau du complexe lagunaire du Sud-Ouest du Bénin : cas du lac Ahémé-Gbèzoumè. Thèse de Doctorat unique, Université d'Abomey-Calavi, Bénin, 139 p.

Fiogbé E, Dossou-Yovo A, Ogouwalé E. 2007. Rapport National sur l'Environnement Marin et Côtier du Bénin. Ministère de l'environnement, Bénin, 68 p.

Guillard M, Lang J, Lucas J. 1982. Etude sédimentologique des milieux de mangrove du Bénin occidental (Afrique de l'Ouest) : Actes Symposium International sur les lagunes côtières, SCOR/IABO/UNESCO, Bordeaux, 129137.

Houéto OF. 2013. Etude pour la restauration et de gestion des forets sacrées des sites Ramsar 1017 et 1018 du Bénin : Rapport final cartographie site Ramsar. Projet PPD 165/12REV.1(F), Bénin, 81 p.

Katemo MB, Colinet G, André L, Chocha MA, Marquet J, Micha JC. 2010. Evaluation de la contamination de la chaine trophique par les éléments traces $(\mathrm{Cu}, \mathrm{Co}, \mathrm{Zn}, \mathrm{Pb}$, $\mathrm{Cd}, \mathrm{U}, \mathrm{V}$ et As) dans le bassin de la Lufira supérieure (Katanga/RD Congo). Tropicultura, 28(4): 246-252.

Leme DM, Marin-Morales MA. 2008. Chromosome aberration and micronucleus frequencies in Allium cepa cells exposed to petroleum polluted water-A case study. Mutation Research, 650(1): $\quad 80-86 . \quad$ DOI: 10.1016/j.mrgentox.2007.10.006

Mama D. 2010. Méthodologie et résultats du diagnostic de l'eutrophisation du lac Nokoué (Bénin). Thèse de Doctorat, Université de Limoges, Limoges, 157 p.

MDDELCC. 2015. Critères de qualité de l'eau de surface au Québec: fondements des critères de qualité pour chaque usage de l'eau. MDDELCC, Québec. 
www.mddelcc.gouv.qc.ca/eau/critères_e au/fondements.htm

Müller G. 1981. Die Schwermetallbelastung der sedimente des Neckars und seiner Nebenflusse: eine Bestandsaufnahme. Chemiker Zeitung, 105: 157-164.

Nature-Tropicale ONG. 2006. Plan d'action stratégique pour la gestion rationnelle et communautaire des ressources biologiques et des écosystèmes des sites et des couloirs de migration du lamantin d'Afrique de l'Ouest dans les zones humides du Sud-Bénin. Nature-Tropicale ONG, Benin, 83 p.

PGPE (Plan de Gestion de Plan d'Eau). 2008. Complexe fluviolacustre, Lac AhéméChenal Aho-Lagune côtière. PGPE, Benin, $38 \mathrm{p}$.

Rank J, Nielsen MH. 1997. Allium cepa anaphase-telophase root tip chromosone aberration assay on N-méthylnitrosourea, maleic hydrazid, sodium azide, and ethyl methanesulfonate. Mutation Research/Genetic Toxycology and Environmental Mutagenesis, 39: 121-127.

Traoré A, Soro G, Kouadio EK, Bamba BS, Oga MS, Soro N, Biemi J. 2012. Evaluation des paramètres physiques, chimiques et bactériologiques des eaux d'une lagune tropicale en période d'étiage: la lagune Aghien (Côte d'Ivoire). Int. J. Biol. Chem. Sci., 6(6): 7048-7058.

DOI: http://dx.doi.org/10.4314/ijbcs.v6i6.40

Wedepohl KH. 1995. The composition of continental crust. Goechimica and Cosmochimica Acta, 59(7): 217-1232.

WHO. 2011. Guidelines for drinking-water quality $\left(4^{\text {th }}\right.$ eds). World Health Organization: Genève, Suisse. http://whqlibdoc.who.int/publications/20 11/9789241548151_eng.pdf

Yèhouénou-Pazou AE. 2005. Les résidus de pesticides chimiques de synthèse dans les eaux, les sédiments et les espèces aquatiques du bassin versant du fleuve Ouémé et du lac Nokoué. Thèse de Doctorat unique, Université d'AbomeyCalavi, Bénin, 217 p.

Youssao A, Soclo HH, Bonou C, Fayomi B. 2011. Evaluation de la bioaccumulation $\mathrm{du}$ plomb dans les espèces animales marines et identification des sources de contamination métallique par une analyse multi élémentaire en métaux $(\mathrm{Al}, \mathrm{Cd}, \mathrm{Cr}$, $\mathrm{Cu}, \mathrm{Pb}$ ) dans les eaux côtières du Bénin. Int. J. Biol. Chem. Sci., 5(1): 188-195. DOI : 10.4314/ijbcs.v5i1.68097 